chp. 7, Academic, New York p. 611 (1970).

4) J.A.Harrison and H. R. Thirsk, Electroanalytical Chemistry, vol. 5, Marcel Dekker, New York p. 68 (1971).

5) A. R. Despič and K. I. Popov, Modern Aspect of Electrochemistry, No. 7, Plenum, New York p. 199 (1972).

6) M. M. Waldrop, COMPLEXITY, The Emerging science at the Edge of Order and Chaos, Sterling Lord Literistic, New York (1992).

7) I. Prigogine, From Being to Becoming, chp. 5, W. H. Freeman and Company, San Francisco (1980)

8) D. M. Mohilner, Electroanalytical Chemistry, vol. 1, Marcel Dekker, New York p. 241 (1966).

9) R. Aogaki and M. Asanuma, Materials Science Forum, 192, 101 (1995).

10) A. Tadano, M. Asanuma and R. Aogaki, J. Cryst. Growth, 166, 1111 (1996).

11) R. Aogaki, J. Electrochem. Soc., 142, 2954 (1995)

12) R. Aogaki, J. Chem. Phys., 103, 8616 (1995).

13) R. Aogaki, E. Yamanoto and M. Asanuma, J. Electrochem. Soc., 142, 2964 (1995).

14) R. Aogaki, A. Yamada and A. Tadano, J.Chem. Phys., 103, 8602 (1995).

15) M. Asanuma and R. Aogaki, J.Chem. Phys, 106, 9930 (1997).

16) A. Tadano and R. Aogaki, J. Chem. Phys., 106, 6126 (1997).

17) M. Asanuma and R. Aogaki, J.Chem. Phys., 106, 9936 (1997).

18) A. Tadano and R. Aogaki, J. Chem. Phys., 106, 6138 (1997).

19) M. Asanuma and R. Aogaki, J.Chem. Phys., 106 ,
9944 (1997).

20) A. Tadano and R. Aogaki, J. Chem. Phys., 106, 6146 (1997).

21）この点は核生成でしばしば用いられているAvramiの方 法による電流一時間曲線のカーブフィッティングを行つ て議論するやり方 ${ }^{1,22)}$ とは全く異なる。この方法では議 論は常に単一のカーブのみに対して行われるだけで, 複 雑な溶液組成の効果を論ずることが出来ないという点を 指摘するだけで十分であろう。

22) B. Scharifker and G. Hills, Electrochim. Acta, 28, 879 (1983).

23) M. Asanuma and R. Aogaki, J. Electroanal. Chem., 396, 241 (1995)

24) R. Aogaki, K. Kitazawa, Y. Kose and K. Fueki, Electrochim. Acta, 25, 965 (1980).

25) R. Aogaki and T. Makino, Electrochim. Acta, 26, 1509 (1981).

26) R. Aogaki, J. Electrochem. Soc., 129, 2442 (1982).

27) R. Aogaki, J. Electrochem. Soc., 129, 2447 (1982).

28) R. Aogaki and T. Makino, J. Electrochem. Soc., 131, 40 (1984).

29) R. Aogaki and T. Makino, J. Electrochem.Soc., 131, 46 (1984)

30) R. Aogaki and T. Makino, J. Chem. Phys., 81, 2154 (1984).

31) R. Aogaki and T. Makino, J.Chem. Phys., 81, 2164 (1984).

32) T. Makino, R.Aogaki and E. Niki, J.Chem. Phys., 81, 5137 (1984).

33) T. Màkino, R. Aogaki and E. Niki, J. Chem. Phys., 81, 5145 (1984).

\title{
3 隔膜系における非線形振動現象
}

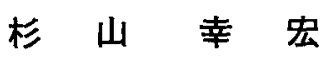

\section{1 はじめに}

本研究の目的は, 生体内情報処理に係わる非線形振動 を, 電気化学的手法を用いて人工的に実琴し, かつ工学 的に応用することにある. 近年, 生体内の情報処理メ力 ニズムにおける非線形振動現象の役割が注目されている. 例え代ウサギの暞覚 ${ }^{1-4)}$ や猫の視覚 ${ }^{5,6)}$ 等, 生物の外界 情報の認識過程において, 非線形振動現象加巧みに利用 されていることが報告されている。これらの生物は, 非 線形振動を用いた情報処理機構により，外界情報を効摔

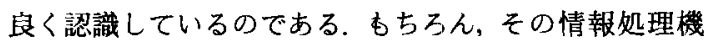
構は, 既存のコンピュータの情報処理機構とは全く基な

三洋電機㑣東京情報通信研究所（干113-0033 東京都文京区本郷 3-10-15 MP ビル)

\section{るあのである。}

これまでに，導電性高分子ポリピロールを用い，その 電気化学的挙動をべースにした安定な電流振動の発生素 子(ポりピロール隔膜系非線形振動子) の構築に成功し ている7)、本稿では，この非線形振動子の種々の特性か ら情報処理素子への応用展開までを紹介する。

\section{2 隔膜系における電気振動の発生}

ポリピロール (PPy) と脂質二分子膜の複合膜を隔膜 とした系に拈いて, Kotowski ら ${ }^{8)}$ は興味深い電気的振 動を得ている.しかし，この系では電気掁動を再現性良 く発生させることは，実質上困難であった，我々はPPy 膜を用い，より再現性のある電気振動系を目指した。ポ 
リカーボネート膜 (PCM) 上に化学重合した PPy 膜を $\mathrm{KCl}$ 溶液相の隔膜とし, かつ一方の溶液相には電子供 与体 $\left(\mathrm{Na}_{2} \mathrm{SO}_{4}\right)$ を, 他方には電子受容体 $\left(\mathrm{FeCl}_{3} 6\right.$ $\mathrm{H}_{2} \mathrm{O}$ ）を添加した系で, 自発的な電位振動発生の実験を 行った. その結果, 非平衡な化学エネルギーの下, 非周 期ではあるが再現性の良い膜電位振動を実現することが できだ, ${ }^{10)}$.この系では, 隔膜を挟んだ両電解質の濃度 差に依存した振動の振幅を実現することができた。しか し，原理的に過渡的な振動であるため，長時間の安定な 振動を得るには至らなかった. 次に同様の隔膜系に定電 位制御を施した系において，PPy の酸化還元反応に基 づくより安定な電流振動系の実現を目指した. その結果, 安定な電気振動の発生に成功することができた ${ }^{11)}$.この 振動系は, PPy が酸化型と還元型の 2 つの安定状態を 有することと選択的イオン透過性（アニオン選択性）を 有すること视市用することにより得られたものであ る. 以下, この振動系を PPy 隔膜系非線形振動子と呼 ふ..

\section{PPy 隔膜系の電位制御下における非線形振動}

Fig. 1 KPy 隔膜系非線形振動子の測定時の外観図 を示す 7 .テフロン膜に固定され，白金線でリードを取っ た金のミニグリッド（1000 mesh）電極をテフロン製セ ル間に配置し, 両セルに $0.1 \mathrm{M}\left(\mathrm{M}=\mathrm{mol} \mathrm{dm}^{-3}\right)$ ピロー ル $(\mathrm{Py})$ と $0.1 \mathrm{M}$ 支持電解質水溶液を満たし, 定電流電 解によって金ミニグリッドを支持体としたPPy 膜を得 た.PPyは，ミニグリッドの穴を埋め尽くすように重合 $\left(10 \mathrm{C} \mathrm{cm}^{-2}\right.$ 程度) した. 水洗後, $0.1 \mathrm{M}$ 支持電解質を両 セルに満たし，金一PPy 膜を作用極とし，Fig. 1 に示 すような電極配置下で PotentiostatによりPPy 膜の 酸化電位と還元電位の間の電位を印加した。 Potentiostatは, 作用極と参照極の間に設定した制御電位に 保つために対極と作用極の間に補償電流を流す． $\mathrm{Cl}^{-}$を ドープしたポリピロール膜 ( $\mathrm{PPy} / \mathrm{Cl}$ 一膜) に $+0.3 \mathrm{~V}$

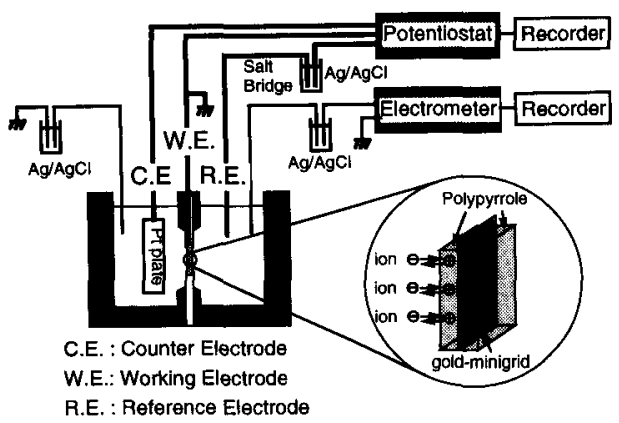

Fig. 1 Schematic illustration of the system used to measure the current and the transmembrane potential under constant potential electrolysis. vs. $\mathrm{Ag} / \mathrm{AgCl}$ を印加した時に得られる電流変化を測定 した (Fig. 2(a)). 同時に, むう一対の参照電極と Electrometerを用いて膜電位变化を测定した (Fig. 2(b)). 電流および膜電位共に非常に安定した振動か観察された。

重合時および測定時の支持電解質に $\mathrm{KCl}$ を使った典 型的な場合を用い，振動のメカニズムの概要を説明する. 両電解質槽の初期 $\mathrm{KCl}$ 濃度は同一とする. 電解重合に より作製された PPy 膜のドーパントイオンは $\mathrm{Cl}^{-}$であ り，作製直後は酸化状態にある.まず, 振動発生の初期 過程（きっかけ）を考える. 規制電位を初期酸化電位よ り低い電位に設定し, Potentiostatによる電位制御を 開始すると，電位補償のために PPy 膜 ( $\mathrm{PPy} / \mathrm{Cl}$ 膜) の還元反応が始まり膜中の $\mathrm{Cl}^{-}$が膜外の電解質槽内に 放出され始める. 電解質槽が 1 つだけからなる通常の電 気化学系では, 一過性の電流を観測するだけで反応は終 了してしまう.しかし，本系のように膜で隔てられた 2 つの電解質槽を有する系では, 対極側電解質槽のみの $\mathrm{Cl}$ 一濃度が増大し, 参照極側では変化しないという濃度 の不均衡が発生する.PPy隔膜は選択的イオン（アニオ ン) 透過性を有するため, 两電解質槽間に生成される $\mathrm{Cl}^{-}$ 濃度差に起囚した膜電位差を形成する．また，この濃度 の不均衡は PPy 膜を酸化する側に㗢くため, 電位制御 を自己触媒的に加速することになる. その結果, 電位制 御は設定電位を飛び超えて PPy 膜を過剩に還元してし まう。

次に Fig. 2 の定常振動のメカニズムを Fig. 3 を用 いて説明する．Fig. 3 は (a) 本非線形振動子（測定系) の等価回路之, (b) 電流・膜電位振動の過程で生ずる各 イベントとの時間的関係を示す.ここで改めて説明する までもないが，本振動系が“非線形”たる主たる由縁は 主に Fig. 3 (a) の回路中の PPy の電気化学反応であ る.この反応の左包は $\mathrm{PPy}^{+}$と $\mathrm{Cl}^{-}$の自己触媒効果を示 している.PPy膜の過剩還元により，電位制御が酸化反

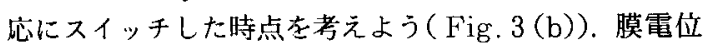
差が負のまま電流の極性が十に転じている。ここで, 既

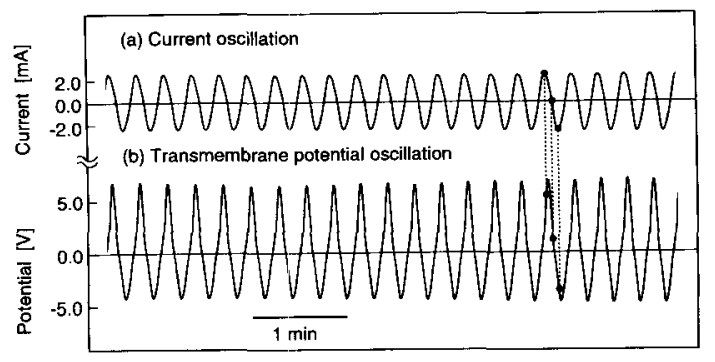

Fig. 2 Current oscillation (a) and transmembrane potential oscillation (b) in a PPy membrane doped with $\mathrm{Cl}^{-}$. 
(b)

(a)

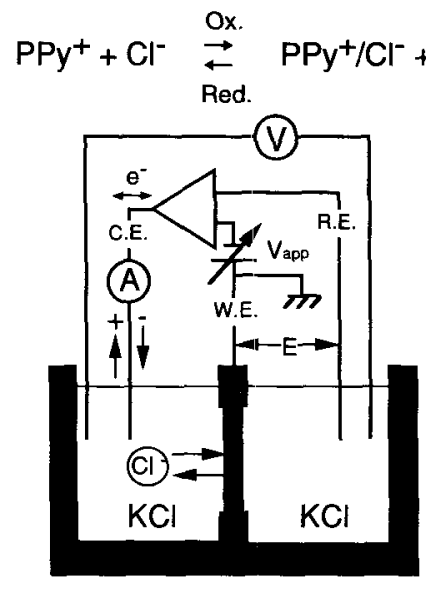

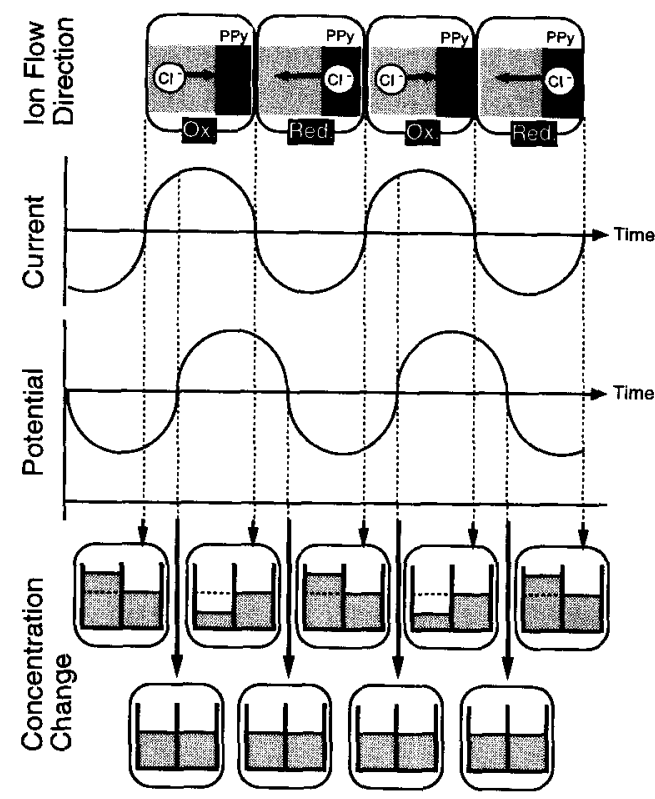

Fig. 3 (a) Equivalent circuit of the PPy membrane oscillator. (b) Various events during the electrical non-linear oscillation observed in the PPy membrane oscillator.

に膜電位差 $\left(\mathrm{Cl}^{-}\right.$濃度差) がこの時点で負のピークを過 ぎていることに気が付く.これは, 酸化反応 $\left(\mathrm{Cl}^{-}\right.$の取 り込み）が始まる以前に $\mathrm{Cl}^{-}$濃度差の臨界点が来て, $\mathrm{Cl}^{-}$ の PPy 膜への戻りが始まっているからであると考えて いる，逆に，この $\mathrm{Cl}^{-}$の逆流が電位制御による還元反応 の減速に寄与していると6考えている. 次の酸化反応か ら還元反応への逆方向のスイッ千同様の過程を経る. 以上の繰り返しによって定常振動が生ずると考えている。

\section{PPy 隔膜系非線形振動子の振動特性}

\section{1 基本特性}

Fig. 2 の電流振動乙膜電位振锄の位相を比較すると 明らかなように, 電流振動の位相か门膜電位振動の位相よ り常に $\pi / 8$ 程度遅れている ${ }^{13)}$.この理由は前章で触れ たように，振動メカニズムと密接に関わっている.

Fig. 4 (a) は, PPy/Cl 膜の場合における膜厚に対す る掁幅と周期の関係を示す．膜厚が厚くなるにつれて振 幅は小さくなり周期は長くなる。これは, 膜厚が厚くな ることに伴う膜厚方向の反応時間のずれと, 抵抗の増加 に伴う反心速度の低下に起因する.Fig. 4(b)では対電 極側の $\mathrm{KCl}$ 電解質溶液の塩濃度変化させた時の振幅 と周期の変化を示す. 塩濃度が増加するにつれて振幅は 増大し, 周期が減少している.メカニズムのところであ 触れたように, ドーパントアニォン $\left(\mathrm{Cl}^{-}\right)$の出入りは, 膜と対極側の電解質槽の間でのみ起こる. 溶液中の塩濃 (a)

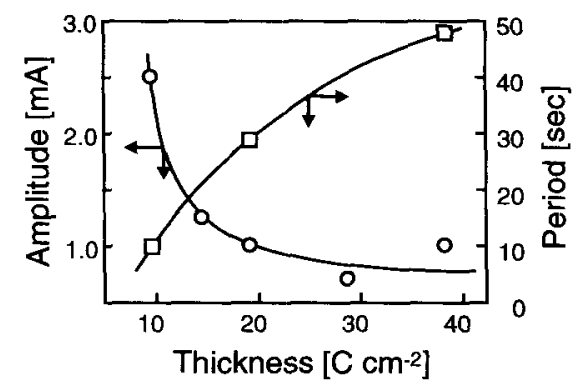

(b)

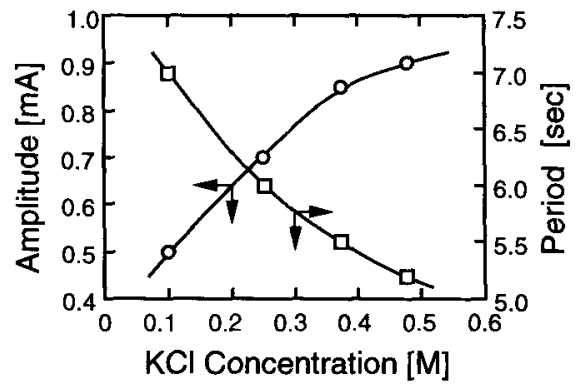

Fig. 4 (a) Dependence of the membrane thickness on the amplitude of the redox current and the period of the current oscillation observed in PPy membrane doped with $\mathrm{Cl}^{-}$. (b) Dependence of the $\mathrm{KCl}$ concentration in the cell of the counter electrode side on the amplitude (oxidation current) and the period of the current oscillation. 
度が増加すれば，アニオンの膜中へのドープが速くなり 周期が短くなる，一方, PPy 膜中の反応の総量は変化し ていないので, 短時間で反応が終了するように振幅が増 大する.

振動挙動は, 膜重合時のドーパントアニオンの種類 と, 各々をドープした時の膜構造に大きく影響される.

Fig. 5 は各々ドーパントアニオンに (a) polyvinylsulfate (PVS ${ }^{-}$), (b) cloride $\left(\mathrm{Cl}^{-}\right)$, (c) p-toluenesulfonate $\left(\mathrm{TsO}^{-}\right)$を用いた時の各電流振動である。（a）, (b)，(c) は振動周期の長い順に並べてある.ドーパント アニオンの種類に依存し, 種々の振動波形が観察される. しかしこれらを比較して分かるように，ドーパントアニ オンが振動周期や波形などにどのような機構で影響を及 ぼすかを簡単なメカニズムで説明することはできない. $\mathrm{PVS}^{-}$は巨大重合アニオンの典型例として用いた。この 場合, PVS-はPPy の中にランダムに取り込まれたま ま身動きすることができないので，代わりに他の軽いイ オン $\left(\mathrm{Cl}^{-}\right.$or $\left.\mathrm{K}^{+}\right)$が出入りするのであろうと考えられ る. 振動周期屯 30 秒 : 20 秒 $\left(\mathrm{PPy} / \mathrm{PVS}^{-}: \mathrm{PPy} / \mathrm{Cl}{ }^{-}\right)$ と, $\mathrm{Cl}^{-}$の場合と大差ない. 同様に, $\mathrm{TsO}^{-}$のイオン半 径は $\mathrm{Cl}^{-}$のイオン半径より非常に大きく, $\mathrm{Ts}_{\mathrm{s}}^{-}$イオン が出入りするとは考え難い，他の軽いイオンが出入りし ていると考えたはうが自然であろう。しかし，それにし ても $\mathrm{TsO}$-の場合の振動周期は $\mathrm{Cl}^{-}$の場合の 1/10しか

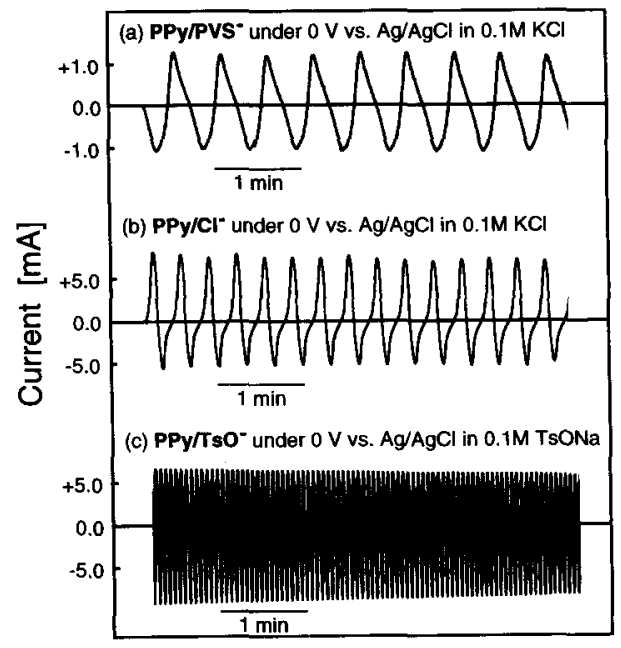

Fig. 5 Various types of current oscillations observed in PPy membranes (a) doped with PVS under constant potential electrolysis at $0 \mathrm{~V}$ vs. $\mathrm{Ag} / \mathrm{AgCl}$ in an aqueous solution containing 0.1 $\mathrm{M} \mathrm{KCl}$, (b) doped with $\mathrm{Cl}^{-}$under $0 \mathrm{~V}$ in $0.1 \mathrm{M}$ $\mathrm{KCl}$, and (c) doped with $\mathrm{TsO}^{-}$under $-0.4 \mathrm{~V}$ in $0.1 \mathrm{M} \mathrm{TsONa}$.
なくあまりにも短周期すぎる。井関ら ${ }^{14)}$ の報告では, $\mathrm{TsO}^{-}$は $\mathrm{PVS}^{-}$と異なり $\mathrm{PPy}$ 膜との電解重合によって ランダムでは無く，ある眣序を保って配向することが明 らかにされている，また，その配向性に起因した特暴な 酸化還元挙動む報告されている. $\mathrm{TsO}^{-}$の場合の短周期 振動は，この膜の秩序構造に起因するのであろう。

以上の結果は, ポリピロールに限らず導電性高分子の 性質を制御することによって，振動挙動を自由に制御で きる可能性を示している.

\section{2 非線形振動子の相互協調作用}

生体内に限らず, より複雑な情報処理は複数の素子が 協調し合うことによって行われる，新規な情報処理素子 へのアプローチの試みとして, 複数の振動子間での相互 作用の実験も行った. 具体的には, 重合条件の異なる 2 つの PPy 隔膜系非線形桭動子の対極側どうしを塩橋ま たは白金線で接続し，電流振動变化を測定した ${ }^{13,15)}$. 塩 橋結合の場合は 2 つの振動子の間でイオンの移動が可能 であり，いわゆる抵抗性の結合を形成した場合である。 一方, 白金線結合の場合は電子のみの移動が可能であり, イオンからすればいわゆる容量性の結合を形成した場合
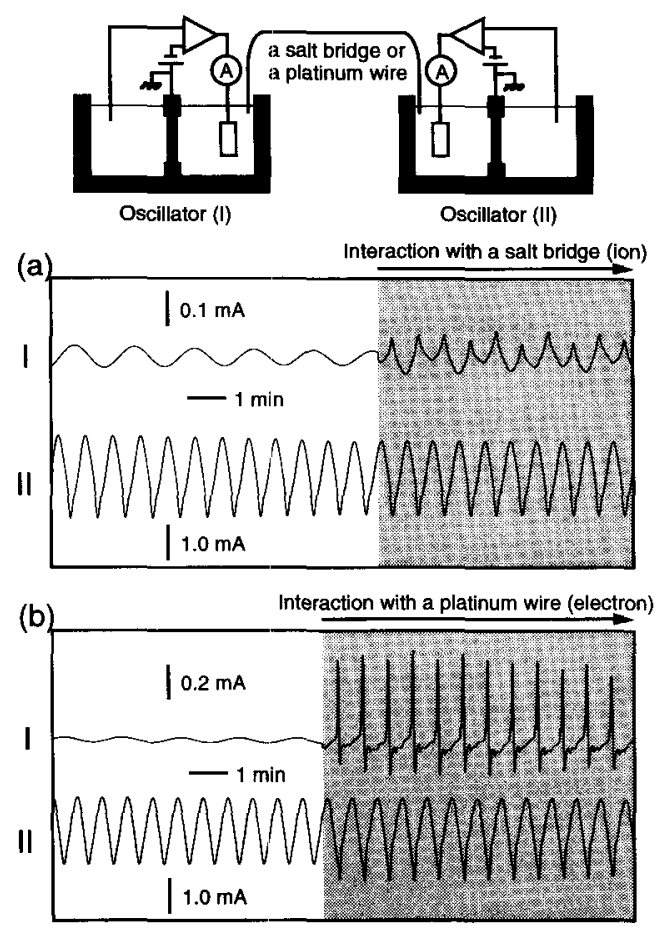

Fig. 6 Experimental setup to measure the synchronization behavior and the typical responses when the counter electrode sides of two PPy membrane oscillators were connected with (a) a salt bridge or (b) a platinum wire. 
である.Fig. 6 は (a) 塩橋と（b）白金線で結合した場 合の一例である. いづれの結合の場合む 2 つの振動子間 で振動の強度がより強い方に，ほぼ逆位相で引き込まれ ているのを観察することができた，また，白金線の結合 では容量性結合の特徴である微分波形を示している。し かし、いづれの場合も結合後の振動周期は結合前の振動 強度の強い振動の周期と一致しており，結合が “弱い韭 線形結合”であることを示している．Fig.7は，塩橋の $\mathrm{KCl}$ 濃度を変えることによって結合強度を変化させた 時の結果である. 濃度 $1 \mathrm{M} \mathrm{KCl}$ の塩橋を用いた場合 （Fig.7(a)）には，結合中む結合前の振動周期を保っ ている. それに対して飽和 KCl を用いた場合 (Fig. 7 （b）には, 結合中の振動には一見して明確な周期とい うるのが無い. 結合強度が增したためであると考えられ る. いづれにしても, 振動子の結合強度を変化させるこ とによって, 振動子どうしの相互作用強度を制御できる ことが明らかである。

\section{5 振動型化学センサへの展開}

\section{1 味物澌のセンシング}

本非線形振動子を情報処理素子として応用するための 具体的アプローチとして, 振動ベースの化学センサの可 能性を検討した ${ }^{13)}$. 先に明らかにしたように, 対極側せ ルの電解質塩濃度変化によって报動の振幅や周期が変化 する，その場合には電解質の濃度をを变化させたが, 本章 では電解質溶液中のイオン種を变えた場合の振動変化 （変調）について論ずる.最初の試みとして, 本振動子を
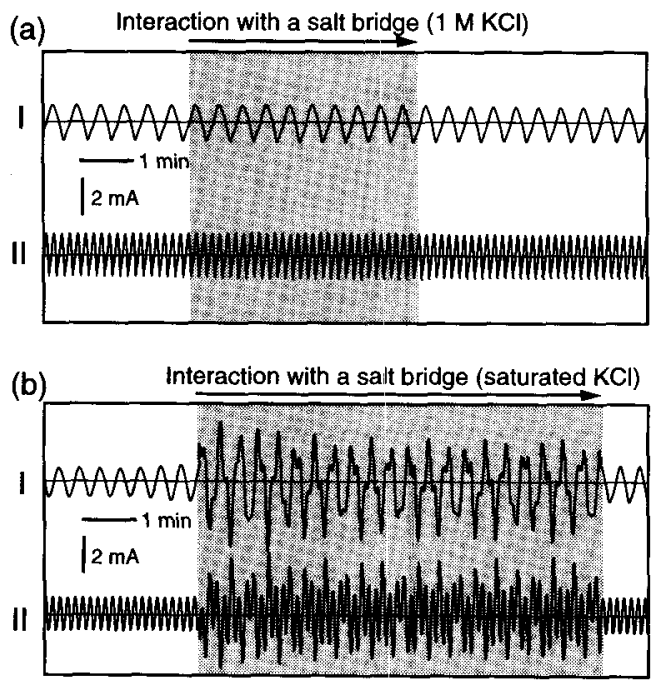

Fig. 7 Various responses caused by the interaction when the counter electrode sides of two PPy membrane oscillators were connected with salt bridges (1 $\mathrm{M} \mathrm{KCl}$ : (a), saturated $\mathrm{KCl}$ : (b)).
用いた味センサの可能性を検討した. $\mathrm{PPy} / \mathrm{Cl}$ 膜を用い, 定常振動の最中に対極㑡セルに塩酸，硫酸キニーネ，フ ルクトースなどを添加すると, 添加物質每に異なる振動 変調が観察される（Fig. 8).これらの添加物質は, 各々 酸味、苦味，甘味に相当する物質である．味物質添加後 の振動波形は，添加物質毎に全て異なっている．この結 果は本非線形振動子が味 (化学) センサとしての展開の 可能性を示唆するものである. しかし，味物質といって もその組成は多様である. 本結果のような振動の変化が 常に観察できるとは限らない，系統的な議論をするため にはさらにデータ数を増やす必要がある.

\section{2 添加物質の識別}

本非線形振動子は原理的に添加物質の種類を識別する ことが可能である. アルキルアルコールを用いた種類の 識別を例に挙げる. $\mathrm{ClO}_{4}$ ををドーパントイオンに用いた PPy 隔膜系非線形振動子にメタノール, エタノール, 1 -
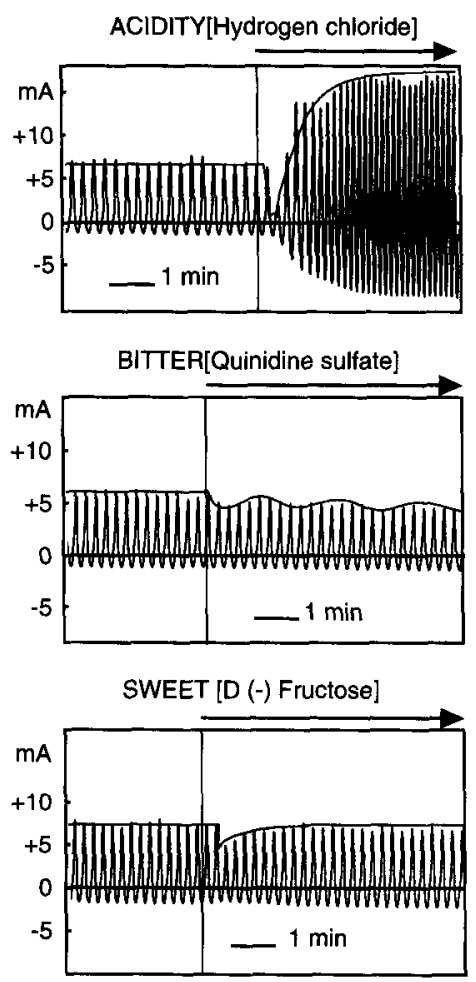

Fig. 8 Various types of modulations of current oscillations observed when the different types of specimens, namely, hydrogen chrolide (acid taste), quinidine sulfate (bitter taste), or D (-) fructose (sweet taste), were added to the counter electrode side to get prepared with $10 \%$ concentration in the cell. 
プロパノール，1-ブタノールをそれぞれ対極側電解質 溶液の容積比が 10\%になるように添加した際に生ずる 振動変調を調べた ${ }^{15)}$. 結果を Fig. 9 (a)-(d)に示す. メ夕ノール $\left(\mathrm{CH}_{3} \mathrm{OH}\right)$ の場合, 添加直後に振動か減衰・ 消隇する. 逆に1-ブタノール $\left(\mathrm{C}_{4} \mathrm{H}_{9} \mathrm{OH}\right)$ 添加の場含 には変化が全く観察されなかった，一方この両者の間の アルキル鎖長を有するエタノール $\left(\mathrm{C}_{2} \mathrm{H}_{5} \mathrm{OH}\right)$ と 1 - プ ロパノール $\left(\mathrm{C}_{3} \mathrm{H}_{7} \mathrm{OH}\right)$ の場合において, 振動の振幅, 周期および波形の変化が観察された。 エタノールと 1 プロパノールとあに添加量を増加させるに従って単調に 周期が增大し，かつ初期波形からの変化も大きくなる.

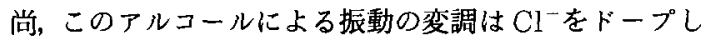
たPPy膜系では観察されなかった。アルコールの種類 に依存した振動の変調が、ドーパントイオン種と添加物 質のイオン種の組み合わせに依存するという興味深い事 実が明らかになった。

また, エ夕ノールと1-プロパノールでは変調後の波 形が全く異なるので, 逆にその波形から添加したアルコー ルの種類と濃度がある程度識別できる，Fig. 10 は，1プロパノールを添加する前後の 1 周期分の電流振動波形 を比較したものである，振動変調後の波形には，変調前 の波形に無かった変曲点が現われている. 変曲点の出現 する位置（位相）は, 添加物質の違いはもちろん，添加 濃度の違いによっても变化している．この事実は非線形 振動の発生過程に添加物質が介入することに由来し, 各 添加物質固有の電気化学的パラメータに依存して変曲点 の出現数や位㯰が変化する，従って，変調振動波形の八 ターン（変曲点に関するデータ）から添加物質を識別す ることも可能となると考えている.

以上は，アルコールの場合に限らない一般的事実と考 えられ，本非線形振動子が振動をべースとした今までに
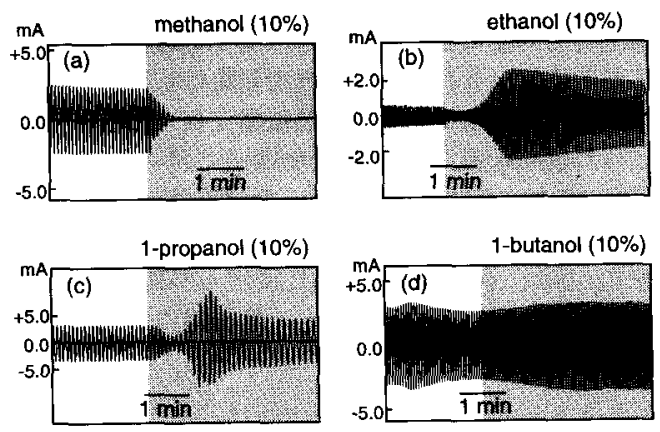

Fig. 9 Various responses of the current oscillations observed in PPy membrane doped with $\mathrm{ClO}_{4}{ }^{-}$in $0.1 \mathrm{M} \mathrm{LiClO}_{4}$ (applied potential: $+0.1 \mathrm{~V}$ vs. $\mathrm{Ag} / \mathrm{AgCl}$ ) when various alkyl alcohols were added to the counter electrode side to get prepared with $10 \%$ concentration in the cell.

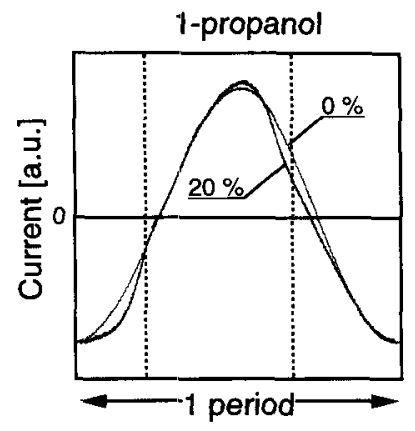

Fig. 10 A period of the current oscillation when 1propanol were added to the counter electrode side to get prepared with (a) $0 \%$ or (b) $20 \%$ concentration in the cell.

ない原理の化学センサ（振動型化学センサ）へと展開可 能であることを示している。

\section{6 まとめ}

導電性高分子の PPy 膜を隔膜とし, 定電位制御を行 うだけで酸化還元反応に基づく安定な電流振動を発生さ せることができる、ところでここれる゙に研究されてい る振動のモデルシステム ${ }^{17-20)}$ は基本的にエネルギー消 費をする系である. 一方, 本 PPy 隔膜系非線形振動子 は外部からの電位制御という形でエネルギー供給をする 系であり，メカニズムの上であ原理的に安定な系である. これはデバイス化の観点から非常に有利であると考えて いる.

本稿では PPy 隔膜系非線形振動子の発生する振動の 振幅, 周期及び波形は, 膜厚, 塩濃度, ドーパントイオ ン, 電解質への添加物質等のパラメータによって制御可 能であることを示した. また，複数の振動子を接続する ことによっても振動の相互作用による変調が起こること を示した. 最後に, 本 PPy 非線形振動子をべースにし た振動型化学センサの可能性を提示することにより, 非 線形振動子の情報処理素子への応用展開への一方向を示 した.

PPy 隔膜系における本非線形振動は, まだほんの数 年前に見出されたばかりである. 今後, PPy膜の重合膜 構造の振動に及ばす影響, 物質添加に上る振動変調メ力 ニズムの解明等, 多くの課題を明らかにすることが必要 である.

\section{文献}

1) W. J. Freeman and G. V. D. Prisco, Behav. Neurosci., 100, 753 (1986).

2) W. J. Freeman and B. Baird, Behav. Neurosci., 101, 393 (1987).

3) S. L. Bressler, Behav. Neurosci., 102, 740 (1988). 
4) K. A. Grajski and W.J. Freeman, Behav. Neurosci., 103, 790 (1989).

5) C. M. Gray, P. König, A. K. Engel and W. Singer, Nature, 338, 334 (1989).

6) R. Eckhom and H.J. Reitboeck, (Eds., H. Haken and M. Stadler), Synergetics of Cognition Springer-Verlag, Berlin Heidelberg, p. 99 (1990).

7) M. Iseki, M. Ikematsu, Y. Sugiyama, I, Tago and A. Mizukami, J. Electroanal. Chem., 386, 253 (1995).

8) J. Kotowski, T. Janas and H. Tien, Bioelectrochem. Bioenerg., 19, 283 (1988).

9) M. Iseki, M. Ikematsu, Y. Sugiyama and A. Mizukami, Bioelectrochem. Bioenerg., 34, 149 (1994).

10) Y. Sugiyama, M. Iseki, M. Ikematsu and A. Mizukami, Physica D, 84, 280 (1995).

11) M. Iseki, M. Ikematsu, Y. Sugiyama, I. Tago and A. Mizukami, J. Electroanal. Chem., 386, 253 (1995)

12) P. Burgmayer and R.W. Murray (Ed., T.A.Skotheim),
Handbook of Conducting Polymers, Vol. 1, Marcel Dekker, New York, p. 507 (1986).

13）杉山幸宏, Molecular Electronics and Bioelectronics, 7 (4) (1996)

14) M. Iseki, K. Saito, M. Ikematsu, $Y$. Sugiyama, K. Kuhara and A. Mizukami, J. Electroanal. Chem., 358 221 (1993)

15）杉山幸宏，井関正博，池松峰男，関口達彦，'95 年電気化 学秋季大会講演要旨集, $2 \mathrm{~K} \mathrm{09}, 226$ (1995).

16) Y. Sugiyama, M. Ikematsu, T. Sekiguchi and M. Iseki, Review of Polarography, 42 (3/6), 46 (1996).

17) K. Yoshikawa, K. Sakabe, Y. Matsubara and T. Ota, Biophys. Chem., 21, 33 (1985).

18) K. Toko, M. Tsukiji, S. Ezaki and K. Yamafuji, Biophys. Chem., 20, 39 (1984).

19) Y. Kobatake, Adv. Chem. Phys., 29, 319 (1975).

20) J. Arisawa and K. Misawa, J. Membrane Sei., 32, 223 (1987)

\section{本会図書案内}

\section{（続） 電気化学測定法}

\section{$<$ A 4 版，本文 158 ページ，定価 3, 500 円（送料別) >}

(9)内 容

1. 電気化学测定の基礎（I）イオン伝導・電子伝導の 测り方, 2. 電気化学测定の基礎 (II) 電気化学セル におけるオーム損の测定，3. 電気化学测定の基礎 （III）ポテンショスタットの活用一動作原理上演算増 幅器の利用, 4. 電気化学测定の基礎 (IV) 電気化学 测定装置のコンピュータ化，5.サイクリックボル夕 ンメトリー－（I）測定の基礎，6.サイクリックボル タンメトリー（II）非水系の CV 測定, 7. クロノア ンペロメトリー，8，インピーダンス测定法一基礎 (I) 交流インピーダンス，9. インピーダンス測定法一 基礎（II）固体系取扱の基礎，10. インピーダンス测 定法－基礎（III）固体電解質，11. インピーダンス测 定法一応用（I）鹰食系への適用，12. インピーダン ス测定法一応用（II）䉓池系への適用，13．インピー ダンス湘定法一纫用（III）様々な伝達関数，14. 電極 電解液界面に打ける赤外反射分光法, 15. 電気化学 系におけるその場測定法としての紫外可視吸収分光法，
16. エリプソメトリー之顕微エリプソメトリー, 17. 微小電極を用いる電気化学測定法, 18. マイクロバン ドアレイ電極を用いた電気化学測定法, 19. 回軽リン グディスク電極, 20. チャンネルフロー電極法, 21 . In Situ 電気化学水晶振動子マイクロバランス法, 22. 走查型振動電極, 23. 電気化学 STM 法, 24. 原 子レベルで制御した電極表面とその反応性，25．ポリ マー電解質の電気化学, 26. ポリマー二次電池とその 基礎特性評価, 27. 特殊な環境で用いる参照電極 (I) 溶融塩を対象にした参照電極，28. 特殊な環境で用い る参照電極 (II) 固体電解質を対象にした参照電極, 29. 特殊な環境で用いる参炤電極（III）高温水を対象 にした参照電極，30．特殊な眇境で用いる参照電極 (IV) 地中および海水で用いる参照電極

(9)申込先

干102-0074 東京都干代田区九段南 4-8-30 アルス市ヶ 谷202 社団法人電気化学会 (03-3234-4213, FAX 03-3234-3599) 